\title{
UNINTENDED CONSEQUENCES: REPRESENTATIONS OF RWANDAN WOMEN AND THEIR CHILDREN BORN FROM RAPE
}

\begin{abstract}
Karen Crawley and Olivera Simic ${ }^{*}$
Abstract. This article analyses an exhibition of photographs of Rwandan women and their children born from rape, as an occasion for exploring how the racialised and gendered subjects of international law are imagined and how a certain politics of humanitarianism is mobilised around the notions of rescuer and victim. While human rights documentary can make a critical contribution to awareness, policy debate and advocacy efforts, we argue that exhibitions like Intended Consequences can unintentionally perpetuate the politics of victimhood and reinforce the assumptions of patriarchy. Certain modes of framing and staging the suffering of the racialised 'other' can easily become a mere opportunity to show compassion, which functions to affirm the humanity of the witness. But within the aesthetic experience of receiving testimony and viewing photographs there are opportunities to re-imagine those subjects and to rethink the politics of humanitarian engagement.
\end{abstract}

Between April and July 1994, Hutu extremists killed almost a million Tutsi and moderate Hutu in the Rwandan genocide. ${ }^{1}$ As in other instances of mass violence, perpetrators used sexual violence as a weapon, and raped, tortured and mutilated between 250,000 and 500,000 women and girls, mostly Tutsi. ${ }^{2}$ The thousands of children born of these rapes are infamously described by Rwandans as 'enfants du diable' (Devil's children), 'enfants non-desirés' (unwanted children) or 'enfants manvais souvenirs' (children of bad memories). ${ }^{3}$ While some women abandoned their children, and

* Karen Crawley and Olivera Simic are lecturers at the Griffith Law School and members of the Socio-Legal Research Centre (SLRC), Griffith University, Queensland, Australia; k.crawley@griffith.edu.au and o.simic@griffith.edu.au. The authors wish to thank Lisa Cuklanz, Coel Kirkby, James Parker, Tim Peters, Peter Rush, the editors of the AFLJ and the two anonymous referees, and conference participants at Affective States of International Criminal Justice at the University of Melbourne in July 2011 for their comments on this paper.

1 The United Nations estimates the total number of people killed at 800,000. Between 10-25\% of this figure were Hutus. United Nations Report of the Independent Inquiry into the Actions of the United Nations during the 1994 Genocide in Rwanda New York 1999.

2 See further Nowrojee Bianifer Shattered Lives: Sexual Violence during the Rwandan Genocide and its Aftermath Human Rights Watch New York 1996; Association de Veuves du Génocide d'Avril AVEGA-AGAHOZO Étude sur les violences faites aux femmes 1999 at 33; Organisation of African Unity Rwanda: The Preventable Genocide OAU Addis Ababa Ethiopia 2000; Bijleveld Catrien, Morssinkhof Aafke \& Smeulers Alette 'Counting the Countless: Rape Victimization During the Rwandan Genocide’ (2009) 19:2 International Criminal Justice Review 208.

3 The National Population Office of Rwanda estimates the number of children born of forced impregnation to be between 2,000 and 5,000. Victim groups provide information that places the figure at anywhere between 10,000 and 25,000. See further United Nations, Security Council, Letter dated 1 October 1994 from the Secretary General addressed to the President of the Security Council, S/1994/1125, 4 October 1994; Mukangendo Marie Consolée 'The Struggles of Rwandan Women Raising Children Born of Rape' in Torgovnik Jonathan Intended Consequences Aperture New York 2009 p 3 at 5 and Mukangendo 
some committed infanticide, others decided to keep their babies despite facing rejection by their families and communities. ${ }^{4}$ In the years following the genocide, the Rwandan government lacked the infrastructure and resources to meet survivors' critical needs, and grassroots survivor-run organisations assumed a primary role in assisting survivors with therapy, housing, food, medical treatment, income-generating training, and assistance to support the large numbers of children they look after. In 2009 the United Nations General Assembly again called for urgent international and national initiatives to assist survivors of the Rwandan genocide, in particular orphans, widows and survivors of sexual violence, through medical care, skills training and victim support. ${ }^{5}$

The Rwandan genocide, along with ethnic cleansing in the former Yugoslavia, transformed international legal understandings of sexual violence from the private actions of individuals to a public and political tool of genocide. ${ }^{6}$ Historians have demonstrated that the ethnic identities of Hutu and Tutsi are shifting political constructs rooted in the socio-economic arrangements of colonialism. ${ }^{7}$ Scholars of sexual violence have drawn on these insights to show that the genocide was 'a gendered, nation-building process inscribed on the physical body' of Tutsi women 'in order to fuse an "imagined" Hutu nation in the minds of an otherwise regionally and classdivided Hutu populace. ${ }^{8}$ In the years preceding the genocide, Tutsi women were portrayed in the media as sexual predators, objects of temptation for Hutu men, and threats to the homogeneity of Hutu blood. ${ }^{9}$ Rape thus served as a means to degrade and subjugate Tutsi women, as well as Hutu women married to Tutsi men, who protected Tutsi individuals, or who were affiliated with Tutsi. ${ }^{10}$ 'In raping a woman, a man identified himself as Hutu/male and his victim as Tutsi/female in a way that at once avoided complex histories of inter-marriage and cohabitation and represented the logic of superiority.'11 Even newborn babies or pregnant women were not spared, including those of Hutu origin, if their babies were fathered by Tutsi men. ${ }^{12}$ The physiological and psychological complications of rape, and the destitution of those survivors

Marie Consolée 'Caring for Children Born of Rape in Rwanda' in Carpenter R Charli (ed) Born of War: Protecting Children of Sexual Violence Survivors in Conflict Zones Kumarian Press Bloomfield Conn. 2007 p 40.

4 See further Nowrojee above note 2 at 3, 79-80.

5 64th General Assembly, 22 December 2009 http://www.un.org/News/Press/docs/2009/ga10908.doc.htm (last accessed 1 May 2012).

6 See the landmark case of Prosecutor v. Akayesu, Case No. ICTR-96-4-T, Judgment, 1 731-34 (Sept. 2, 1998).

7 Prunier Gérard The Rwanda Crisis: History of a Genocide Columbia University Press New York 1995; des Forges Alison Leave None To Tell the Story: Genocide in Rwanda Human Rights Watch New York 1999; Mamdani Mahmood When Victims Become Killers: Colonialism, Nativism, and the Genocide in Rwanda Princeton University Press Princeton 2001; McClintock Anne Imperial Leather: Race, Gender and Sexuality in the Colonial Contest Routledge London 1995 at 353, 359.

8 Baines Erin 'Body Politics and the Rwandan Crisis' (2003) 24:3 Third World Quarterly 479 at 479-480.

9 The infamous "Ten Commandments of the Bahutu" published in the influential Rwandan newspaper Kangura in 1990 ascribed sexual prowess to Tutsi women. See Nduwimana Françoise The Right to Survive: Sexual Violence, Women and HIV/AIDs International Centre for Human Rights and Democratic Development Montreal 2004 at 17; Chrétien JeanPierre Rwanda: les médias du génocide Karthala Paris 2005.

10 See Nduwimana as above at 14 and 18.

11 Mirzoeff Nicholas 'Invisible Again: Rwanda and Representation after Genocide' (2005) 38:3 African Arts 36 at 86.

12 Mayor of Taba Jean-Paul Akayesu made a public statement to the effect that if a Hutu woman were impregnated by a Tutsi man, the Hutu woman had to be found in order 'for the pregnancy to be aborted.' P v J.P. Akayesu, Case No. ICR96-4-T, Judgement, 2 September 1998, para. 121-124. 
widowed, orphaned, or abandoned, led many women to tell investigators that death would have been a preferable fate. ${ }^{13}$

The voices of these survivors have not often been heard in public discourse, either nationally or internationally. Indeed, many of the women who made legal history by testifying to sexual violence at the International Criminal Tribunal for Rwanda were left without medical treatment and have since succumbed to their illnesses. ${ }^{14}$ In the last few years, there have been efforts to collect and publicise these women's stories for an international audience. ${ }^{15}$ This article focuses on one such effort, Jonathan Torgovnik's exhibition Intended Consequences, comprising photographs of Rwandan women and their children, accompanied by testimonies in which the women recount the sexual violence they endured and their feelings towards the child that resulted. The exhibition, which has appeared in several forms-as a book with accompanying DVD, ${ }^{16}$ a travelling exhibition, ${ }^{17}$ excerpted in magazines, ${ }^{18}$ and on a website hosted by MediaStorm ${ }^{19}$ - has received many journalism awards and praise for bringing attention to an under-recognised humanitarian issue. ${ }^{20}$ Along with collaborator Jules Sterne, Torgovnik created Foundation Rwanda to manage the income arising from this exhibition, aimed at connecting women survivors of sexual violence with existing support services, funding secondary schooling for the children born of rape, using photography and new media to raise awareness of the consequences of sexual violence in genocide. ${ }^{21}$

Human rights documentary projects such as this one aim to give voice to particular victims of suffering, create awareness of human rights violations, and generate empathy among an international audience. The exhibition Intended Consequences does not reveal a problem for our contemplation, but actively shapes the boundaries of this problem, determining how we engage with it. In this article, the exhibition serves as an occasion for reflecting on some of the tensions which characterise international law, human rights, and humanitarian discourse. Part 1 positions

13 Nowrojee above note 2 at $49-59$.

14 See Nduwimana above note 9 at 29; Nduwimana Françoise ‘Women and Rwanda's Genocide: What Goes Unsaid' (2004) 14:2 Libertas p.1.

15 de Brouwer Anne-Marie \& Hon Chu Sandra Ka (eds) The Men Who Killed me: The Rwandan Survivors of Sexual Violence Douglas \& McIntyre Vancouver 2009 at 19.

16 Torgovnik Jonathan Intended Consequences Aperture New York 2009. The book contains about 30 testimonies; the DVD that accompanies the book contains 16 testimonies (36 minutes) as well as a documentary called 'An Unspoken Language' which is an interview with Jonathan Torgovnik (11.5 minutes).

17 In early 2009, the Aperture Foundation, the Open Society Institute, Amnesty International and Foundation Rwanda launched an international travelling exhibition of this work.

18 Aperture Magazine published the photographs with short excerpts of testimony: http://www.aperture.org/gallery/images/ic.pdf (last accessed 1 May 2012).

19 The photographs and testimonies first appeared online in 2008: http://www.mediastorm.com/publication/intendedconsequences (last accessed 1 May 2012) alongside 'An Unspoken Language' and an additional 15 minute video, 'Intended Consequences,' which narrates the events of the genocide and takes short excerpts from each of the individual testimonies.

20 Awards include the American Photography Award 2010; PDN: 2010 Annual Competition -Intended Consequences (Aperture 2009); duPont Journalism Award 2010, Columbia University Graduate School of Journalism (2010); World Press Photo 2009 -Arnato Opera in New York; National Portrait Gallery 2007 -Intended Consequences. For favourable coverage see Fineman Mia 'Children of Bad Memories: Photographing a Generation Born of Rape during the Rwandan Genocide’ Slate Magazine 10 June 2009 http://www.slate.com/id/2219840/ (last accessed 1 May 2012).

21 http://www.foundationrwanda.org/ (last accessed 1 May 2012). 
the exhibition within the prevailing humanitarian iconography of a racialised (foreign, exotic, 'African') victim (with no political agency, depoliticised, and experiencing private pain and suffering). Part 2 examines how the women's testimonies are judged, found wanting, and redeemed within the exhibition's overarching narrative of idealised mother-as-nurturer. Part 3 focuses on the photographs in the exhibition, examining the affective experience of viewing these photographs, and how this shifts according to the context of their presentation. Intended Consequences helps us to pinpoint how the racialised and gendered subjects of international law are imagined and how a certain politics of humanitarianism is mobilised around the notions of rescuer and victim. In so doing, it raises the possibility of imagining those subjects and that politics otherwise.

\subsection{FRAMING THE EXHIBITION: RESCUER AND VICTIM}

The photographs of the women and children in Intended Consequences are arranged in the manner of traditional portrait photography, but with the subjects gazing directly into the camera. The book, titled Intended Consequences: Rwandan Children Born of Rape, focuses on the children, who are photographed alone- the women are photographed only with their children, and thus shown in relation to them. The exhibition which appears on the DVD and website, simply called Intended Consequences, shows additional photographs of the women alone, with a voiceover narrating a shortened version of their testimony. ${ }^{22}$ These testimonies can be viewed separately under each woman's name, and also edited together into a 14 minute video, which was nominated for 2009 Emmy Award. Each testimony begins directly with the outbreak of violence, and recounts a story of unimaginable violation and suffering, loss and agony, the realisation that they were pregnant, their ongoing struggle with physical and mental injury, their intensely complicated feelings towards their children, and their desperate need for economic, social and psychological assistance. Each woman lives in poverty, their lives marked by isolation, stigma and shame.

On the website and video, we listen to the women recount graphic details of sexual violence, while looking at a slideshow of close-up photographs of their anguished faces and tears, as though the photographer has captured them in the midst of recounting their stories. We only briefly hear one of the women's original voices, speaking Kinyarwanda-the sixteen testimonies are recited in English by only three distinct female voices, adding to the feeling of numbing repetition. The slideshow of Valentine's testimony contains a series of still photographs of her in distress, pressing her fingers into her forehead, with ominous drumbeats on the soundtrack. When she describes the rape itself_- The head of the militias came. He put a spear in my leg and forced me to be apart' - the photograph of her fades to a black screen and the voiceover says, with emphasis: 'He ruthlessly raped me... for four hours.' After this black screen the child appears for the first time, photographed with her mother. The editing thus connects the act of violence and the issuance of the child, conflating the existence of the latter with the horror of the former.

22 The testimonies were translated by Geoffrey Ngiruwonsanga and narrated in the videos by Rosette Adera, Yvette Rugasaguhunga, and Hope Kantete. 
The exhibition is framed by Torgovnik's personal narrative, which follows the familiar framework of humanitarian engagement with the suffering of others: a personal discovery of injustice, followed by the compulsion to devote oneself to helping. ${ }^{23}$ Torgovnik began his 'personal journey'24 in 2006, when he was in East Africa on an assignment for Newsweek and encountered a woman who had been raped during the genocide and contracted HIV, and had also borne a child. He returned to Rwanda on a 'mission' 25 to record these women's stories and photograph them and their children. Torgovnik wrote a foreword to the book, spoke at the exhibition launch and to the media, and was interviewed in a short video entitled 'An Unspoken Language' which appears on the DVD and the website and in which he recounts that he too suffered trauma, stating 'you can't prepare for something like that,' and that he was 'hyperventilating,' 'having nightmares,' and 'not being able to sleep sometimes.' Torgovnik thus appears in the exhibition as 'a bridge character,' Nicholas D. Kristof's term for white characters who function in stories about Africa as an apparently necessary point of identification for American readers. ${ }^{26}$ The figure of the white hero allows a predominantly non-African audience to vicariously partake in a feeling of moral superiority at having braved personal hardship to bring a difficult story to light. ${ }^{27}$ Torgovnik's efforts have been praised as altruistic and innovative, as 'an example' of 'an effort to use [photography] to expose issues and bring about change, ${ }^{28}$ with one magazine even claiming that until he came along, 'these women... had not been taken seriously nor been able to express themselves.' 29 Torgovnik writes that 'these women feel they have lost their dignity, that they are alone and utterly powerless.' 30

Very few people are giving attention to these victims. These people have no power. There needs to be someone who comes there and is able to not speak for them but give them the space for their voices to be heard. I'm a messenger for them. That's what I feel I am. ${ }^{31}$

The discourse of 'messenger' within which Torgovnik finds himself positioned, and which governs the pattern of how his work is received, is part of a larger history of Western encounters with Africa, which tend to view Africa and its women as mute, child-like, dependent, and

23 For an outstanding example of such a narrative, see Mia Farrow's preface in Hamilton Rebecca Fighting for Darfur: Public Action and the Struggle to Stop Genocide Palgrave MacMillan New York 2011 p. ix.

24 'Foreword' in Torgovnik above note 16 p.1 at 1.

25 Intended Consequences Panel Discussion Aperture Gallery New York 29 April 2009 http://www.aperture.org/exposures/?p= 3957 (last accessed 1 May 2012).

26 Kristof Nicholas Q3: NYTimes Columnist Nicholas D. Kristof Answers Questions http://www.facebook.com/video/ video.php?v=424427794200 (last accessed 1 May 2012).

27 See Moore Jina 'Ethical or Exploitative? Stories, Advocacy and Suffering' in Taub Amanda (ed) Beyond Kony 2012: Atrocity, Awareness and Activism in the Internet Age LeanPub 2012 p. 73 at 77.

28 Hopper Jeannie ArtonAir Interview 'Photography and Activism' 8 October 2010: http://artonair.org/show/photography -activism-michelle-bogre-jonathan-torgovnik (last accessed 1 May 2012).

29 'Jonathan Torgovnik' 83:29 European Photography Art Magazine 2008 p. 3 http://www.europeanphotography.com/pdf/ webEP83.pdf (last accessed 1 May 2012).

30 'Foreword' in Torgovnik above note 16 p.1.

31 Jonathan Torgovnik Interview Lighthouse Films Aperture Gallery New York March 2 2010. http://www.youtube.com/ watch?v=1JZ2qf2EzKo\&feature= related (last accessed 1 May 2012). 
requiring Western care and guidance. ${ }^{32}$ As Nigerian-American novelist Teju Cole has recently observed: 'Africa has provided a space onto which white egos can conveniently be projected. It is a liberated space in which the usual rules do not apply: a nobody from America or Europe can go to Africa and become a godlike saviour or, at the very least, have his or her emotional needs satisfied.' 33 Philanthropic celebrities like George Clooney, Bob Geldof, Bono, and Angelina Jolie function in the media as 'symbols of mobility and modernity,' 34 transforming Africa into 'a brandcontinent' 35 and relegating its citizens 'to the role of exotic Others ready to be consumed.' 36 Torgovnik recounts that the women interviewed 'didn't want their stories to be told within the community, but they really wanted the world to know... I promised them that I will try to take their words and give them the space to express themselves, to give them a voice outside of Rwanda. I felt it a mission. ${ }^{37}$

Initially conceived only as a magazine or book article, the project subsequently 'took on a larger life' and was posted online, which raised the prospect that the exhibition could be seen in Rwanda. Torgovnik stated that while he 'promised the women not to publish them in Rwanda,' the nature of publishing in magazines meant 'there is no way to control that one hundred percent,' and after consulting with a few members of AVEGA (Association de Veuves du Génocide d'Avril - the Association of Widows of the Genocide), he decided that the impact of the exhibition on the Western public outweighed the risk of harm to the women and children in their home country that could be posed by placing the photographs online. ${ }^{38}$ Although their names have been changed, the faces of the photographic subjects in Intended Consequences are clearly identifiable. This runs contrary to guidelines developed by international agencies for reporting on children who face the risk of retribution or stigmatisation. For instance, UNICEF cautions against categorising or describing children in a way that may expose a child to negative reprisals, discrimination or rejection by their local communities, suggesting that in order to minimise these risks, the names of children should be changed and their visual identity obscured. ${ }^{39}$ In Bosnia and Herzegovina, for instance, women who have been victims of rape and children born of rape are

32 McMillan Nesam “'Our Shame”: International Responsibility for the Rwandan Genocide’ (2008) 28:1 Australian Feminist Law Journal 3 at 20.

33 Cole Teju 'The White Savior Industrial Complex' The Atlantic 21 March 2012 http://www.theatlantic.com/ international/archive/2012/03/the-white-savior-industrial-complex/254843/ (last accessed 1 May 2012).

34 Repo Jemima \& Yrjola Riina 'The Gender Politics of Celebrity Humanitarianism in Africa' (2011) 13:1 International Feminist Journal of Politics 44.

35 As above.

36 Volcic Zala 'Former Yugoslavia on the World Wide Web: Commercialization and Branding of Nation-states' (2008) 70:5 International Communication Gazette 395.

37 Above note 25.

38 As above.

39 'Always change the name and obscure the visual identity of any child who is identified as [...] a victim of sexual abuse or exploitation' and 'avoid categorisations or descriptions that expose a child to negative reprisals -including additional physical or psychological harm, or to lifelong abuse, discrimination or rejection by their local communities.' UNICEF, 'Reporting Guidelines To Protect At-Risk Children' Section III: http://www.unicef.org/media/media_tools_ guidelines.html. World Vision states that 'photos should respect human dignity and... not portray people as helpless victims,' and that 'photos should not fully identify a sexually abused person of any age' and that 'publishing conventions include images that are in profile, or darkened, from the back, or obscure part of the face if it is a full-face shot.' World Vision, 'Protocol for Communicating about Vulnerable Children and Abuse' Guidelines A. 
protected from public identification. ${ }^{40}$ But there appears to be an exception in Western media when it comes to reporting on Africa. ${ }^{41}$ In 2010, the New York Times published an article by Nicholas D. Kristof with the name and photograph of a nine year old girl in the Democratic Republic of the Congo who was raped by rebel soldiers. The article contained detailed description of her family and home town, and reported that she has contracted a sexually transmitted disease. ${ }^{42}$ The imperative of raising awareness in a Western audience was seen to outweigh ethical concerns about identifying victims of sexual violence: ${ }^{43}$ when challenged on why he printed her name and photograph, Kristof said his actions were appropriate because it was 'the only way to raise the issue on the agenda. ${ }^{34}$

The perspectives of children born of war are largely absent from public discourse, and there are few testimonies by such children in any context. ${ }^{45}$ Their lives are shrouded in secrecy: a traumatised mother, an absent father, and rejection by larger family networks, they are frequently isolated, stigmatised and threatened. International policymakers tend to subsume the special vulnerabilities of children born of rape within broader discussions of gender-based violence. ${ }^{46}$ Carpenter argues that these children must be surfaced and represented to counter this silence and distortion, and that we must expose how 'states, international organisations, and well-intentioned transnational actors (are) implicated in the mistreatment or misrepresentation of these children.' 47 She observes, for instance, that children born of rape are frequently 'constructed not as subjects of human rights concern but as symbols of human wrongs inflicted on other populations.' 48

The exhibition Intended Consequences illustrates this representational tendency. In the book, the close-up portraits of the child's face and the mother's testimony are on facing pages of the

40 In 2003, UNICEF produced a report on children born of rape in Bosnia and Herzegovina - 'war babies' -but it has never been published. Local women's non-governmental organizations who work with women survivors of war-time rape keep this data strictly confidential, and none of the mothers or their children ever appeared in public space.

41 For example, see Murdock Heather 'Congo: a Country of Rape and Ruin' The Washington Times 26 April 2011 http://www.washingtontimes.com/news/2011/apr/26/congo-a-country-of-rape-and-ruin/ (last accessed 1 May 2012) which published a photograph of two girls, aged 9 and 11, who had been raped.

42 Kristof Nicholas D 'Orphaned, Raped and Ignored' New York Times 20 January 2010. The photograph is here: http://www.nytimes.com/slideshow/2010/01/31/opinion/0131Kristof_7.html (last accessed 1 May 2012). Kristof and the New York Times had previously affirmed their policy of not publishing names and photographs of rape victims of any age. Kristof Nicholas D 'A Reason not to Report Rape' New York Times 1 May 2009 http://kristof.blogs. nytimes.com/2009/05/01/a-reason-not-to-report-rape/ (last accessed 1 May 2012).

43 See for instance Mayer Aric 'Ethics, Issues and Responsibilities in Depicting Survivors of Sexual Violence' Media Policy Document for HEAL Africa June 2010 available at: http://aricmayer.blogspot.com/2010/07/photography-and-sexualviolence.html (last accessed 1 May 2012).

44 Kristof Nicholas D 'Is It Ever OK to Name Rape Victims?’ New York Times 4 February 2010 http://kristof.blogs.nytimes. com/2010/02/04/is-it-ever-ok-to-name-rape-victims/ (last accessed 1 May 2012).

45 Nsimire Sara 'Congolese Children Born of Rape Face Dismal Future' Ground Report 1 January 2010 http://www.groundreport.com/World/Congolese-Children-Born-of-Rape-Face-Dismal-Future/2915217 (last accessed 1 May 2012) contains interviews with children who are 7 and 9 years old. For one of the few interview studies with children born of rape, see Volcic Zala \& Erjavec Karmen 'Living with the Sins of their Fathers: An Analysis of Self-representation of Adolescents born of War Rape' (2010) 25:3 Journal of Adolescent Studies 359.

46 Carpenter R. Charli Forgetting Children Born of War: Setting the Human Rights Agenda in Bosnia and Beyond Columbia Uni. Press New York 2010 at 42.

47 Carpenter R. Charli 'Gender, Ethnicity, and Children's Human Rights: Theorizing Babies Born of Wartime Rape and Sexual Exploitation' in Carpenter note 3 p.1 at 3-4.

48 Carpenter above note 46 at 52. 
book, the paired formatting emphasising the link between the mother's suffering and the mute fact of the child's existence. The children remain speechless, not subjects but rather symbols of the crimes narrated by their mother, ciphers of sexual violence, devoid of perspective, burdens to bear. Each child's expression is serious and sombre, staring directly into the camera, as though to depict them as smiling or engaged in activity would undermine the exhibition's narrative of victimhood. Each child forms part of this photographic series by virtue of having been born of rape, yet the fact that they do not know the circumstances of their conception places the viewer in a position of epistemological superiority: as we look at them, we know a seemingly 'defining' truth about them that they themselves do not know. The exhibition has contrived it so that we are placed in that privileged position of greater knowledge: we are the omniscient witness, reinforcing the West's self-conception as a distanced observer. ${ }^{49}$

Critical approaches to the discourse of human rights and humanitarianism have identified a constitutive tension between an appeal, on the one hand, to a common humanity and the universal implications of certain events of human suffering, and, on the other hand, to a binary and hierarchical distinction between a Western 'us,' the 'agent' of humanitarianism, and a Rwandan —or simply African- 'them' needing rescue. ${ }^{50}$ The discourse of human rights is defined through the figure of the victim of suffering. ${ }^{51}$ As Slavoj Žižek has written, 'the customary image of the victim is that of an innocent-ignorant child or woman paying the price for politicoideological power struggles. Is there anything more 'non-ideological' than this pain of the other in its naked, mute, palpable presence?'52 This representational schema effects 'a humanitarian reduction of the victim' 53 in which the specificity of their circumstances and experiences is downplayed through their portrayal as 'generically suffering humans in need of assistance.'54 Debates about the ethics and efficacy of awareness-raising campaigns and the imperialist assumptions underlining humanitarianism intensified this year in the wake of the high-profile Kony2012 campaign, widely criticised by journalists, activists, aid workers, and scholars in Uganda and elsewhere for offering an oversimplified, misleading narrative, for failing to provide a context for the conflict, and for portraying Africans as either helpless victims or brutal killers. ${ }^{55}$

49 Blocker Jane Seeing Witness: Visuality and the Ethics of Testimony University of Minnesota Press Minneapolis 2009 at 53.

50 See further McMillan Nesam 'Regret, Remorse and the Work of Remembrance: Official Responses to the Rwandan Genocide' (2010) 19:1 Social \& Legal Studies 85 at 96; Orford Anne 'Muscular Humanitarianism: Reading the Narratives of the New Interventionism' (1999) 10 European Journal of International Law 679; Mutua Makau 'Savages, Victims and Saviours: The Metaphor of Human Rights' (2001) 42 Harvard International Law Journal 201; Fassin Didier 'Humanitarianism as a Politics of Life' (2007) 19:3 Public Culture 499 at 518.

51 Žižek Slavoj Metastases of Enjoyment: On Women and Causality Verso New York 1994 at 213. See further Wall Illan rua 'On Pain and the Sense of Human Rights' (2008) 29 Australian Feminist Law Journal 53.

52 Žižek as above at 213-214.

53 Fassin above note 50 at 517.

54 McMillan above note 50 at 97.

55 See for example Visible Children: Kony 2012, Viewed Critically: http://visiblechildren.tumblr.com/; Cronin-Furman Kate and Taub Amanda 'Solving War Crimes with Wristbands: The Arrogance of "Kony 2012"' The Atlantic 8 March 2012; Zuckerman Ethan 'Unpacking Kony 2012' My Heart's in Accra 8 March 2012 http://www.ethanzuckerman. com/blog/2012/03/08/unpacking-kony-2012/ (last accessed 1 May 2012); Branch Adam 'Dangerous Ignorance: The Hysteria of Kony 2012' Al Jazeera 12 March 2012; Ruge TMS “'Kony 2012” is not a revolution' New York Times 14 March 2012; Taub Amanda (ed.) Beyond Kony 2012: Atrocity, Awareness \& Activism in the Internet Age LeanPub 2012 available at: http:/ / leanpub.com/beyondkony2012. 
Intended Consequences raises similar issues, in constructing its women as victims and its children as mute ciphers of crime, and giving prominence to the narrative framing of a white Western male.

\subsection{TESTIMONY: NARRATIVES OF THWARTEd MOTHERHOOD}

The process of collecting the women's testimonies for Intended Consequences was a conscious and deliberate attempt to give victims a voice, to break the silence surrounding the crimes committed against them, and transform private 'abuses that were experienced individually and hidden away by the individual traumatised subjects' 56 into a collective, public trauma. Collecting and publishing survivor testimony has become a key ritual in international humanitarian discourse. ${ }^{57}$ Such testimonials are often understood to individualise the person of the witness, and shift our emphasis from the perpetrator's inhuman behaviour to the humanity of the victim. The act of receiving testimony is considered crucial for the psychological well-being of the survivors themselves. ${ }^{58}$ As Torgovnik reports, 'Many of the women I've interviewed have waited more than a decade to start healing themselves by telling their stories. ${ }^{59}$ Psychoanalyst Dori Laub explains the necessity of 'a therapeutic process of constructing a narrative, of reconstructing a history and essentially, of re-externalising the event' which can only happen 'when one can articulate and transmit the story, literally transfer it to another outside oneself.' 60 In the telling, the trauma story becomes a testimony, and in the hearing of it the listener engages in 'an act of remembering forward that obliges us to receive rather than repress inhuman events. ${ }^{61}$

Valerie: I have come a long way to be able to sit like we are sitting with you now. There was a time, when we were very quiet, and very silent about this, but it never helped us. But as we talk, we get better.

The idea of testimony as a necessary unburdening has a Christian genealogy which has particular purchase in Rwanda, a predominantly Christian country.

Odette: I always thought I would talk about it, but I was not ready. Now I thank God for enabling me to do it. It is a privilege to have it on tape that I'm going to leave as legacy for those that I love and for those that love me.

56 See Felman Shoshana The Judicial Unconscious: Trials and Traumas in the Twentieth Century Harvard University Press Cambridge MA 2002 at 7.

57 See for instance the Reading of the Testimonies initiative: www.readingofthetestimonies.com (last accessed 1 May 2012).

58 See Minow Martha Between Vengeance and Forgiveness: Facing History After Genocide and Mass Violence Beacon Press Boston 1998 at 66-74.

59 Jonathan Torgovnik, http://www.reportagebygettyimages.com/features/intended-consequences/

60 Laub Dori 'Bearing Witness or the Vicissitudes of Listening' in Felman Shoshana and Laub Dori (eds) Testimony: Crises of Witnessing in Literature, Psychoanalysis, and History Routledge New York 1992 p 57.

61 Judith Herman cited in Hartman Geoffrey 'Memory.com: Tele-Suffering and Testimony in the Dot Com Era' (2000) 19:3 Raritan 1 at 13; De Ycaza Carla 'Performative Functions of Genocide Trials in Rwanda: Reconciliation through Restorative Justice?’ (2010) 10:3 African Journal on Conflict Resolution 9. 
As interviewer and narrator as well as photographer, Torgovnik plays a central role in framing the women's testimonies. Although their accounts are edited into monologues, we know from the regularity of their answers that they were asked a common series of questions, including how they feel towards their children, and what 'message' they would like to give the world.

Yvette: Tell the world when we die we are leaving behind these children. Nobody takes care of them, nobody owns them. These children were born when the world was looking and never came to our rescue.

Didier Fassin observes that people who function as 'victims' within humanitarian discourse 'often willingly submit to the category assigned to them: they understand the logic of this construction, and they anticipate its potential benefits,' ${ }^{2}$ so they 'offer to the humanitarian agents the part of their experience that feeds the construction of them as human beings crushed by fate.' 63 The testimonials address themselves to the international community, but in so doing, they necessarily adopt the position of victims, and this constrains their self-perception. ${ }^{64}$

In the patriarchal culture of Rwanda, women have traditionally been regarded and treated as dependents of their male relatives, defined by their positions as wife and mother. Their participation in the public sphere has traditionally been constrained by 'the idealized [sic] image of women as child-bearers, ${ }^{65}$ and their sexuality controlled by ideas about morality informed and enforced by the Catholic Church. ${ }^{66}$ According to a 1995 report prepared by the Government of Rwanda for the United Nations Fourth World Conference on Women: 'The ideal image of a woman is still generally viewed through the perspective of her maternal role. The woman must be fertile, hard-working, and reserved. She must learn the art of silence and reserve. ${ }^{67}$ When Torgovnik 'pressed' the women he interviewed on their feelings towards their children, he elicited a range of responses. One interviewee said 'I never loved this kid,' but after receiving counselling at AVEGA, 'slowly I started loving my children' (Valentine). Others are ambivalent: 'I don't hate my son. I don't love him either. But I think I am comfortable staying with him’ (Valerie). Some recount their thoughts of killing their child: 'Out of this forced sex and rape, there can't be a human being, I must be carrying an animal in me. I was planning, when the baby comes out, I wouldn't give it my breast, so it will starve, and die' (Esperance). 'After giving birth, I thought of killing it because I was bitter in me. And it is the cause of trauma to me every time I look at this boy' (Isabelle). Others talk about their child as a blessing, a physical, emotional and spiritual support: 'when I look at my son, it is the only thing that keeps me going' (Esperance), 'I think about my son. When I think about his life, he is like a tree without branches. He is my life, and if I didn't have him, I don't know what I would be' (Stella). Many of the women stated that they do not love their children:

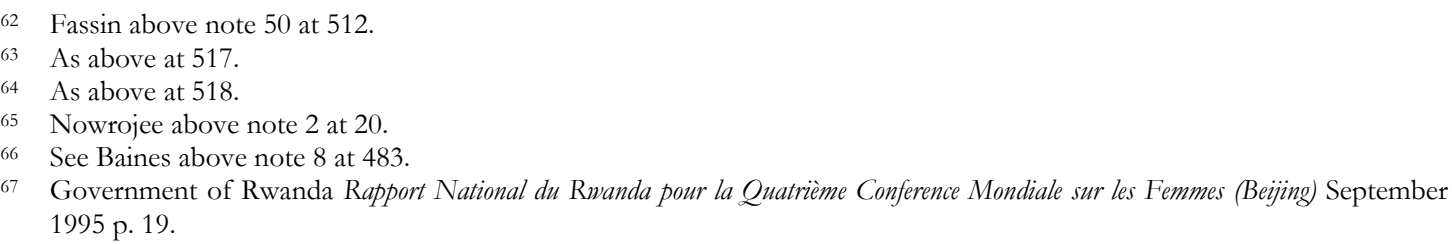


I am a mother, but unwilling to be a mother. I didn't love this child. I didn't make a choice to have this child. Whenever I look at this child, I trigger back to the memories of rape. Whenever I look at her, I imagine those men holding my legs. Maybe with time I will love this daughter of mine. Maybe. But for now. No.

In his interview and commentary on the exhibition, Torgovnik described hearing a mother say she does not love her child as 'a big challenge.' He recounts how he 'pushed that question, 'How can you tell me you do not love your child?' 68 and the women acknowledged that it is terrible saying this as a mother... but this is what I feel.' ${ }^{\prime} 9$ Torgovnik says:

How can you understand something like that? I can't... I can't... [He pauses, shaking his head, then continues.] I really do think that they all love their children, but for many of them it is very hard to admit because of the circumstances, because of the brutality... many of them... or several of them, at least, said: 'We live for our children. These children are our hope. These children are our love. Without these children, we don't think we would survive.' And I loved hearing that too. ${ }^{70}$

As Alison Watson has noted, international policies surrounding children born of rape have been bound up in Western notions of childhood, motherhood and reconciliation which revolve in particular around the 'idealized [sic] figure of the mother-nurturer. ${ }^{71}$ Ideals and normative expectations about motherhood are shaped by systems of authoritative knowledge which reflect male understandings of females as nurturers and providers of emotional sustenance. ${ }^{72}$ Within a patriarchal culture, motherhood is viewed as 'the natural, desired and ultimate goal of all 'normal' women.'73 A typology of 'good' and 'bad' mothers permeates Western legal, political and popular

68 Torgovnik 'An Unspoken Language' above note 16.

69) As above.

70 As above. In the panel discussion he recounts further how he 'pushed' this question with Philomena: 'Philomena just straight on said, You know, I don't love my daughter. And that was a very very difficult thing for me to hear. And I kind of pushed her on that subject. She was very open in talking about this. I said, 'How can you say you don't love your daughter? She's beautiful, she's just twelve. It looks like, you know, you're giving her a good life.' She put her hand on me and she said 'I understand your question very well. And I know this is terrible saying this as a mother..., but for now this is how I feel. Maybe one day it will change.' As above note 25. 'I really think that deep inside they all really do love their children but I don't think they can really say it out front because of the circumstances.' BBC World Service 'Jonathan Torgovnik: Portrait from Rwanda' Interview with Fred Dove 16 November 2007 http://www.bbc.co.uk/ worldservice/programmes/outlook/news/story/2007/11/071115_rwanda_photographer.shtml (last accessed 1 May 2012).

71 Watson Alison 'Children Born of Wartime Rape: Rights and Representations' (2007) 9:1 International Feminist Journal of Politics 20 at 22,31 .

72 Fineman Martha A 'Feminist Theory in Law: The Difference It Makes' in St. Joan Jacqueline and McElhiney Annette Bennington (eds) Beyond Portia: Women, Law \& Literature in the United States Northern Eastern University Press 1997 at 59.

73 Stanworth Michelle Reproductive Technologies: Gender, Motherhood, and Medicine University of Minnesota Press Minneapolis 1987 at 14; Rich Adrienne Of Woman Born: Motherhood as Experience and Institution Norton New York 1976; Miller Tina Making Sense of Motherhood: A Narrative Approach Cambridge University Press Cambridge 2005; Glenn E N Chang G and Forcey L (eds) Mothering, Ideology, Agency and Experience Routledge London 1994; Jetter A Orleck A and Taylor D (eds) The Politics of Motherhood Dartmouth College Press Dartmouth 1997. 
discourse. ${ }^{74}$ As Carol Smart writes, 'a good mother is always available to her children... she supports, encourages... loves and cares for them physically. ${ }^{75}$ The ultimate transgression for a mother is to 'not love' her children.

The women's narratives in Intended Consequences both deny instinctual maternal love, and acknowledge their own efforts to live up to this ideal. Many recount how they have had to learn or train themselves to love their children. Their efforts in this regard show that they recognise that their deviation from their culture's normative expectations of motherhood is unfair to their children. But faced with their honest admissions of ambivalence, Torgovnik disregards their words. He explains that he thinks the women actually do love their children, but cannot admit it to themselves because of the trauma they have experienced. Instead of acknowledging the patriarchal social context in which this violence against women takes place, as well as the necessary limitations of his perspective and understanding, Torgovnik rehabilitates these incomprehensible mothers by framing their testimonies within an overarching narrative of maternal instinctual love. He thus purports to redeem them from the terrible fate of not loving their children enough.

The exhibition's title, 'intended consequences,' suggests that the crimes against these women were carried out primarily in order to impregnate them. While this policy of forced impregnation was characteristic of rape as genocide in the former Yugoslavia, for instance, rape in Rwanda usually preceded murder, or was intended to cause fatal injuries ${ }^{76}$ —including a slow and protracted death by HIV which was wielded deliberately as a weapon. ${ }^{77}$ The notion that the children are the 'intended consequences' of the sexual violence emphasises rape as a crime of biology, of engendering pregnancy, a hijacking of a woman's (rightful) reproductive function. Framing genocidal sexual violence in terms of 'ethnic cleansing' or 'racial hygiene' perpetuates certain myths about identity-that it is genetically determined, that it derives from the father, that some blood is impure, etc.- - which in turn compound the stigma suffered by children born of rape. When approached to record a voice-over for the testimonies in Intended Consequences, one Rwandan woman initially refused to assist 'these sons and daughters of Hutus,' before reconciling herself to the fact that 'they are also sons and daughters of my own people, of my own blood. ${ }^{78}$ Her comment reflects the complex ways in which identity is formed in Rwanda, a paternalistic society in which the final responsibility for the child lies with the male family members and the

74 Kline Marlee 'Complicating the Ideology of Motherhood: Child Welfare Law and First Nation Women' in Fineman Martha Albertson and Karpin Isabel (eds) Mothers in Law: Feminist Theory and the Legal Regulation of Motherhood Columbia University Press New York 1995 p 119.

75 Carol Smart, 'The Woman of Legal Discourse' (1992) 1 Social and Legal Studies 29 at 38.

76 Nowrojee above note 2 at 35.

77 United Nations High Commission on Human Rights 'Fundamental Freedoms: Report of the Special Reapporteur on Violence against Women, its Causes and Consequences, Ms. Radhika Coomaraswamy: Addendum Report of the Mission to Rwanda on the Issues of Violence Against Women in Situations of Armed Conflict' February 1998 cited in Nduwimana The Right to Survive above note 14 at 18; see further Sharlach L 'Rape as Genocide: Bangladesh, the former Yugoslavia, and Rwanda' (2000) 22:1 Emory International Law Review 16 at 99; an estimated 70\% of survivors were infected with HIV, de Brouwer \& Hon Chu above note 15 at 11

78 Above note 25 
identity of the child is expressed with reference to the collective. ${ }^{79}$ In pre-colonial and colonial times when ethnic identities were more fluid, wealthier Hutu men married Tutsi women as a means of social advancement, and their children would be considered Tutsi; after Independence, such a child would be considered Hutu, and by the time of the genocide, all mixed marriages were decreed to produce Tutsi children, so that Hutu men were called upon to kill their own wives and children. ${ }^{80}$ Thus the genocidal sexual violence in Rwanda did not proceed according to a stable racial logic, but rather actively produced ethnic identities through the violent inscription of nationalist ideologies onto the bodies of women.

In naming Intended Consequences from the point of view of the génocidaires, the exhibition perpetuates the assumptions about ethnicity and gender which created the environment for the crime in the first place. ${ }^{81}$ Sexual violence is particularly effective in patriarchal societies in which a woman's worth, status or standing derives from their relationship to the men in their family, from their sexual purity (ie. status as a virgin) or from their role as wives and mothers. The shame of victimisation perpetuates the crime-indeed, the social consequences of the crime are an integral part of the crime itself. But once a child's identity is defined by its father's ethnic identity and the act of sexual violation which took place at conception, the women's contributions to their children's identity are marginalised. The women's suffering and the children's existence are hereby reduced to the effects or products of a larger genocidal narrative which alone gives their lives meaning. Such an exclusive focus on the extreme acts of violence like genocidal rape can function to elide the structural and symbolic violence-the gendered and neocolonial discourses of nationalism, ethnicity and motherhood-which form its less visible but necessary condition. ${ }^{82}$

Survivors of sexual violence can benefit from having testified because they feel that 'others cared enough to listen.' ${ }^{\prime 3}$ This indicates that to testify is more than simply to report an event: it is an address to another, an appeal to an affective community, and to make a claim not just about past suffering but also present and ongoing trauma. ${ }^{84}$ This act of putting into words the anguish and complexity of living with trauma is frequently conceived of as both necessary and impossible. ${ }^{85}$ Necessary because '(i)f the violence of the past remains unrecognized [sic], if it is not remembered, then the past does not pass. ${ }^{86}$ But impossible because of trauma's resistance to being communicated, its tendency to overwhelm or be beyond language, to exceed all ways of

79 This is expressed by Demascene as 'l'enfant est le prolongement de la vie des parents, du nom du clan' (the child prolongs the life of his or her parents and the name of their clan): Demascene J.P. La politique de la protection de l'enfant et de la famille Rwandaise National University of Rwanda 1999 cited in Veale Angela 'War, Conflict, Rehabilitation and Children's Rights in Rwanda' (1999) Trocaire Development Review Dublin 105 at 108.

80 See Baines note 8 at $483,489$.

81 See Weitsman Patricia A 'The Politics of Identity and Sexual Violence: A Review of Bosnia and Rwanda' (2008) 30:3 Human Rights Quarterly 561

82 Douzinas Costas Empire and Human Rights: The Political Philosophy of Cosmopolitanism Routledge New York 2007 at 108 ; Žižek Slavoj Violence Profile Books London 2008.

83 de Brouwer \& Hon Chu above note 15 at 4.

84 Felman Shoshana 'Education and Crisis; Or the Vicissitudes of Teaching" in Felman and Laub (eds) above note 60 p 1 at 3 .

85 Felman Shoshana 'The Return of the Voice: Claude Lanzmann's Shoah' in Felman and Laub (eds) above note 60 p 204 at 224

86 Perrin Colin and Veitch Scott ‘The Promise of Reconciliation’ (1998) 4:1 Law Text Culture 225 at 225. 
capturing or transmitting it. ${ }^{87}$ To put one's trauma into words is to risk losing 'the event's essential incomprehensibility, the force of its affront to understanding.' 88

Brigette: I don't know if you can understand what I went through. Just imagine someone coming to you and telling you: 'Go sleep with another one, and sleep with another one, and another one and sleep...' Even now as I talk to you about it, I don't think you understand it as I want you to understand it. But I am also happy that at least you will go and tell your people that the girls and women in Rwanda went through untold suffering.

As Cathy Caruth suggests, precisely insofar as it overwhelms our capacity for understanding, testimony allows for the possibility of 'a truly historical transmission,' of grasping a historical truth which exceeds all frames of reference or rationalisation. ${ }^{89}$ It is critical, then, to enable or pay attention to the ways in which such testimony exceeds our capacity for understanding, and not to foreclose its meaning or power, but allow it to open up new possibiities of thinking, speaking and writing otherwise about the meaning and implications of the genocide. A collection of testimonies is more than a historical record or a source of information; it belongs also to aesthetic experience. ${ }^{90}$ The ways in which the photographs and women's testimonies resist or unsettle attempts to fix their meaning is the subject of the following section on affect.

\subsection{AfFect: LOOKING AT PHotographs}

Photography has played a critical role in the emergence of a modern human rights consciousness and the formation of an international community which is called upon to respond to mass violence. ${ }^{91}$ As cultural theorist Sharon Sliwinski has argued, 'the very recognition of what we call human rights is inextricably bound to a particular kind of aesthetic encounter... a particular visual encounter with atrocity. ${ }^{92}$ An image operates at the level of the aesthetic, provoking an immediate and complex reaction that engages with and builds upon all our assumptions and understandings of the world, reinforcing (or challenging) them. In accessing emotional responses, they can shape our fears and feelings of security or motivate empathy and compassion which in turn motivate further action. Exhibiting these photographs and testimonies to an international audience is meant to create the kind of affective community which will bolster future humanitarian efforts and engagement. This raises the question of affect: how the spectator to the

87 On the nature of traumatic experience, see especially Caruth Cathy (ed.) Trauma: Explorations in Memory Johns Hopkins University Press Baltimore 1995 pp 3-12.

88 As above at 154

89 Above note 87 at 155 .

90 Hartman Geoffrey 'The Humanities of 'Testimony: An Introduction' (2006) 27:2 Poetics Today 249 at 249.

91 Linfield Susie 'The Ethics of Vision: Photojournalism and Human Rights' in Mauro Alessandra (ed) My Brother's Keeper: Documentary Photographers and Human Rights Contrasto Turin 2007 p 13 at 20. See further Cmiel Kenneth 'The Emergence of Human Rights Politics in the United States' (1999) 86:3 Journal of American History 123.

92 Sliwinski Sharon 'The Childhood of Human Rights: The Kodak on the Congo' (2006) 5:3 The Journal of Visual Culture 333 at 334 . 
exhibition feels addressed or implicated by reading these testimonies and viewing these photographs. ${ }^{93}$

The success of an aesthetic encounter does not lie within the framework of understanding, but in its capacity for posing an encounter with difference. No precise formula exists-in historical narration or that of art- to guarantee a thoughtful and engaged response. ${ }^{94}$ Exhibitions such as Intended Consequences can bring about 'an encounter with the real'95 that disorients and profoundly shakes the audience. But reception does not just occur-it has to be enabled by the creation of an affective community between subject and listener or viewer. ${ }^{96}$ The pure conveyance of information is neither possible nor sufficient: 'knowing what happened is a very different matter from actively receiving, let alone understanding it or forming a remedial response on the basis of such knowledge. ${ }^{97}$ Audience responses to stories and representations of suffering are not uniform, but depend on the time, place, and dominant narrative of the exhibition, as well as individual sensibilities and backgrounds. A lot will depend on the material conditions in which the interviewer-photographer, the documentary subjects, and the viewer participate in the exhibition, as well as on how it appears in different media contexts. Depending on how they are displayed and viewed, the same photographs can be read variously as memorialisations of loss, as denunciations of perpetrators, as exhortations to inflict more pain, as calls for peace, or as cries for revenge. ${ }^{98}$ The utilitarian portrait photographs taken of men and women being processed into Tuol Sleng prison for interrogation and execution during the Cambodian genocide first functioned as a roster of traitors, but now exert a profound impact in exhibitions designed to raise awareness of human rights violations. ${ }^{99}$

If documentary is to inspire compassion rather than pity for its subjects, its viewers must not maintain a 'sentimental distance' but 'be stricken in the flesh.' ${ }^{100}$ Walter Benjamin named the sublime power which makes art belong in the true world'101 the 'expressionless,'102 which Shoshana Felman describes as 'the (mute yet powerful) communication of what cannot be said in words,' 103 and Panu Minkkinen as a 'breach or interruptive silence,' the 'brutal experience of

93 Young Alison Judging the Image: Art, Value, Law Routledge London 2005.

94 Hartman above note 90 at 254.

95 Felman Shoshana and Laub Dori "Foreword" to Felman and Laub (eds) above note 60 p.xiii at xvi.

96 Hartman Geoffrey The Longest Shadow: In the Aftermath of the Holocaust Indiana University Press Bloomington 1996.

97 Hartman above note 90 at 249.

98 Zelizer Barbie Remembering to Forget: Holocaust Memory Through the Camera's Eye University of Chicago Press Chicago 1998.

99 See French Lindsay 'Exhibiting Terror' in Bradley Marl Philip \& Petro Patrice (eds) Truth Claims: Representation and Human Rights New Brunswick Rutgers University Press 2002 p 131; and http://www.tuolsleng.com/photographs.php (last accessed 1 May 2012).

100 Hannah Arendt explains that pity is 'the perversion of compassion,' because its concern for the misery of another is unprompted by intimacy or love. To feel compassion, or love directed 'towards specific suffering' and 'particular persons,' is to be 'stricken with the suffering of someone else, as though it were contagious.' Compassion abolishes distance, but pity maintains it, and thus maintains the capacity for cruelty. Arendt Hannah Eichmann in Jerusalem: A Report on the Banality of Evil Penguin Books New York 1990 at 85, see discussion 85-94.

101 Cited in Felman above note 56 at 13.

102 Benjamin Walter 'Goethes Wahlverwandtschaften' in Gesammelte Schriften Band I Æ I Suhrkamp Frankfurt am Main $1974 \mathrm{p}$ 123 at 181.

103 As above. 
suffering that cannot be narrated.' 104 Often words and images cannot express the inexpressiblethis is why Daniel Liesbeskind's design for the Museum of Jewish History in Berlin used architecture to make people feel, rather than listen or see, employing techniques of estrangement and the absences of empty spaces to refuse the reassuring imposition of meaning, 'to leave such events unredeemable yet still memorable, unjustifiable yet still graspable in their causes and effects.' 105

Photography is both representation (art) and reference (documentary). Torgovnik's photographs mobilise both these discourses. At the same time as their aesthetic qualities- their careful composition, technical precision, and colourful symmetry-invite appreciation as art, their aesthetic neutrality draws on the 'real' effect of documentary and its association with objectivity and impartiality. 106 Their 'safe' determined realism belies their constructed nature. The dominant style for memorials is minimalism following the model established by Holocaust memorials, where the formal preference is to allow viewers to 'work through' the trauma rather than 'act it out.' 107 The realist conventional mode of photojournalism often proceeds as if too much artfulness will draw attention to the photograph's materiality as a representation, and lose some necessary connection to the real subject. But since unconstructed and unmediated truth is an illusion, perhaps truth only emerges when that illusion is foregrounded as illusion. Reconstructed, allegorical or surreal photographs may be more effective in making audiences think about trauma and injustice than the argumentative power of 'realism,' of 'showing it like it is.' For instance, Shahidul Alam's exhibition Crossfire, a set of allegorical photographs evoking the extra-judicial killings in Bangladesh, had enough purchase on the 'real world' to incite swift governmental suppression. ${ }^{108}$ Richard Mosse's infrared photographs of the conflict in the DRC, which present the familiar images of militiamen, victims of rape, and displaced people, in striking pinks, purples and blues, present a productive surrealism which forces a reorientation of vision. ${ }^{109}$ These projects reflect the insight behind Benjamin's observation, inspired by Brechtian theatre: 'less than ever does the mere reflection of reality reveal anything about reality... something must in fact be built up, something artificial, posed."110

The subjects photographed in Intended Consequences are abstracted from the reality of their lived existence and arranged in tableau for the camera. They seem to exist rather than live, suspended in the peculiar ahistorical death of photography. ${ }^{111}$ The photographs alone convey

104 Minkkinen Panu 'The Expressionless: Law, Ethics, and the Imagery of Suffering' (2008) 19 Law \& Critique 65 at 84

105 Young James E 'Libeskind's Jewish Museum in Berlin: The Uncanny Arts of Memorial Architecture' (2000) 6:2 Jewish Social Studies 1 at 3.

106 Fisher Cora 'Jonathan Torgovnik: Intended Consequences: Rwandan Children Born of Rape' 3 The Brooklyn Rail March 2009 http://www.brooklynrail.org/2009/03/artseen/jonathan-torgovnik (last accessed 1 May 2012).

107 LaCapra Dominick Representing the Holocaust: History, Theory Trauma Cornell University Press Ithaca 1994; Mirzoeff Nicholas 'Invisible Again: Rwanda and Representation after Genocide' (2005) 38:3 African Arts 36 at 37.

108 Gonzalez David 'Police in Bangladesh Close Photo Exhibit' The New York Times 23 March 2010 http://lens.blogs.nytimes.com/2010/03/23/behind-39/?hp (last accessed 1 May 2012).

109 Stearns Jason 'Shocking Pink' The Guardian 28 May 2011 http://www.guardian.co.uk/artanddesign/2011/ may/28/richard-mosse-infrared-photos-congo

110 Benjamin Walter 'A Small History of Photography' in One-Way Street, and Other Writings (Jephcott Edmund and Shorter Kingsley trans.) NLB London 1979 p 240 at 255.

111 Sontag Susan Regarding the Pain of Others Picador New York 2003 at 24. 
very little of the trauma, violence and degradation of the accompanying stories-a viewer could easily pass over them. Only once we have read the testimony can we interpret the despair in the women's eyes and the watchful gaze of the children, and the images change. Without the photographs, the testimonies depend on the willingness of someone to take the time to listen or read them. As text or narrative, they lack the immediate iconic and indexical power of a photograph, which 'arrests' through its 'instantaneity,' its almost tactile manifestation of 'a shadow, a light, a texture.'112 A photograph is powerful not because of its 'meagre content' but 'the energy - made and ready to explode - that it has harnessed.'113 The direct gaze of the women and children seems intended to establish an emotional connection to the viewer. ${ }^{114}$ Their eyes interrogate us, demanding that we return their gaze. ${ }^{115}$ The affect of this address cannot be fully explained by reference to the photograph's composition and context: 'a residue remains, an ethical truth that cannot be appropriated but that nevertheless calls for a response.'116

The affective power of Intended Consequences lies, then, in the conjoining of neutral photographs and wrenching testimony. But the testimonies anchor the meaning of the photographs in contradictory ways. The Portrait Prize-winning photograph shows a woman with her arms draped around the shoulders of a young girl, while another leans against the wall in the background, gazing listlessly to one side. ${ }^{117}$ The woman's beautifully coloured dress is in stark contrast not only to the plainer ones of her daughters, but also to the cracked earth and simple earth building, and the anguish on her face. She testifies that the older girl was born from her husband, and the younger as a result of the rapes. As viewers, we immediately read this narrative into the image, and conjecture that the girl embraced by her mother is the wanted child, and the girl in the background shadows is the unwanted one, her pink plastic sandal kicked off in the dust a sign of her rejected and forlorn status. But as Torgovnik explains in an interview, the child who is being embraced is the younger child, the product of the rape, and the embrace part of a conscious effort on the mother's behalf to show her child more affection. ${ }^{118}$ Here, the dramatic narrative impact of the photograph turns on a reading which, although powerful, does not reflect the actual relationships being presented.

A photograph can be instrumentalised in different directions depending on whether it appears alongside testimonies or short captions, alone or in a series, as a slideshow or selfdirected exhibition, with a soundtrack or in silence. When Torgovnik's photographs appeared in Aperture magazine, the most suggestive or graphic part of the women's testimony was excerpted below the photograph: 'They raped me one after the other until I couldn't move.' 'It was all

112 Baudrillard Jean The Perfect Crime (Turner Chris trans.) Verso London 1996 at 86-7.

113 Deleuze Gilles Essays Critical and Clinical (Smith Daniel W and Greco Michael A trans.) University of Minnesota Press Minneapolis 1997 at 160.

114 See Michael Fried on the thematics of 'facingness' in Fried Michael Why Photography Matters as Art as Never Before Yale University Press New Haven 2008 at 111.

115 See Benjamin above note 105 at 245; Derrida Jacques Adieu: Farewell to Emmanuel Levinas (Brault Pascale-Anne and Nass Michael trans.) Stanford Uni. Press Stanford 1999.

116 Minkkinen above note 99 at 84 .

117 This photograph can be viewed here: http://www.aperture.org/exposures/?p=1469 (last accessed 1 May 2012).

118 Interview with Fred Dove, above note 70. See also Fisher above note 106. 
brutal. I was still a virgin at the time of the genocide."119 In one photograph, we see a woman and daughter positioned side by side, but with the mother turned away from the child, seemingly evoking her ambivalence and their estrangement. The viewer of this magazine page tracks between the caption and the image, reading the image in light of the testimony, projecting the bodily violation so carefully described by the woman onto the body of, and in, the photograph, belying its calm surface. The juxtaposition obliges the viewer to imagine the photographic subject as the victim of sexual violence- the same way they were perceived by their rapists.

Photography confronts us with our responsibility to and for people we will probably never meet-this is its power, but also its risk. The justification frequently given for publishing photographs of survivors is to put a face on an otherwise abstract crime so that readers will see a human victim rather than a statistic. Allowing oneself to be photographed and one's name to be published is often understood as an act of empowerment or bravery. ${ }^{120}$ Making the faces of these women and children visible may seem to help counter an important invisibility, but as Judith Butler warns, 'personification does not always humanize [sic].'121 'We might think that our norms of humanisation require the name and the face, but perhaps the 'face' works on us precisely through or as its shroud, in and through the means by which it is subsequently obscured.'122 Emmanuel Levinas presented an ethics of the face of the other as the basis of our responsibility towards others, but it was not an actual face. ${ }^{123}$ Occasionally a focus on the face, name or singularity of a person can actually serve to dehumanise them. This is an argument occasionally made in relation to the photographs of Diane Arbus, for instance. Susan Sontag insisted that Arbus's gaze is 'based on distance, on privilege, on a feeling that what the viewer is asked to look at is really other.' 124

In a Western culture where our sensibilities are dulled by graphic depictions of both real and fictional violence in media, television, and film, the emotional 'shock value' of this exhibition is its use value as a media commodity. ${ }^{125}$ These women are not sharing their stories with their fellow Rwandans, they are addressing a transnational audience for whom, as Linda Alcoff and Laura Gray observe, 'the very act of speaking out has become used as performance and

119 See above note 18 .

120 See for example Sheehan Paul 'Refusing to hide, gang rape victim fights back' The Age 22 July 2006 http://www.theage.com.au/news/national/refusing-to-hide-gang-rape-victim-fights-

back/2006/07/21/1153166587230.html (last accessed 1 May 2012). This article is accompanied by a portrait photograph of the rape victim, and the article also named her.

121 Butler Judith Precarious Life: The Power of Mourning and Violence Verso New York 2004 at 141.

122 Butler Judith Frames of War: When is Life Grievable? Verso New York 2009 at 95.

123 'The Levinasian face is not the face captured in a photograph. Whilst photography can work to bring about the ethics of the face, it is not through illustrations of faces.' Foster Nicola 'Photography and the Gaze: The Ethics of Vision Inverted' (2008) 14:2 Parallax 78 at 89, 87.

124 Sontag Susan On Photography Picador New York 2001 at 34. More recently Arbus's identification with her subjects has been interpreted not, as Sontag insists, as a kind of prurient voyeurism, but as 'a way of questioning the limits of looking, the predatory nature of photography, and about our complicity in all this.' O'Hagan Sean 'Diane Arbus: humanist or voyeur?' The Guardian 26 July 2011 http://www.guardian.co.uk/artanddesign/2011/jul/26/diane-arbus-photographysideshow (last accessed 1 May 2012).

125 Stone Philip R \& Sharpley Richard 'Consuming Dark Tourism: A Thanatological Perspective' (2008) 35:2 Annals of Tourism Research 574 at 580 . 
spectacle.'126 Drawn into the conventions of a culture which commodifies death and suffering, an affect not intended by the women becomes the organising principle for how their words are arranged, produced, and edited. Instead of serving therapeutic, informational and affective goals, the published testimonies become material for voyeuristic gratification. ${ }^{127}$ Instead of being transformed by the experience, certain modes of presentation may only enable us to voyeuristically regard the suffering of another while affirming our own humanity.

\subsection{UNINTENDED CONSEQUENCES}

The response of the international community to the genocide in Rwanda and its aftermath has been primarily conceived as a failure to properly bear witness. We looked, but refused to see. ${ }^{128}$ The exhibition Intended Consequences presents the international community with another, belated, opportunity to bear witness to what happened in Rwanda, and to thus redeem ourselves for our initial failure to look. ${ }^{129}$ Even as we are shamed by the enormity of the other's suffering, by 'what some people have to endure,' and even as our own complicity in this suffering is made apparent-'These children were born when the world was looking and never came to our rescue'-we are able to expiate some of that guilt by confronting those testimonies and looking at those photographs. In short, exhibitions like this make us feel bad, which ultimately makes us feel good.

Human rights documentary can make a critical contribution to awareness, policy debate and advocacy efforts. But unintended consequences may arise from the focus, framing and presentation of exhibitions like Intended Consequences. The testimonies are framed in ways which perpetuate the politics of victimhood and reinforce the assumptions of patriarchy. Certain modes of exhibiting these photographs and testimonies together may facilitate voyeuristic gratification, or an opportunity for the viewer to express pity rather than genuine empathy or engagement. As Cole writes, 'The White Savior [sic] Industrial Complex is not about justice. It is about having a big emotional experience that validates privilege. ${ }^{130}$ The staging of another's suffering becomes merely an opportunity to show emotion or compassion, a way of affirming the humanity of the witness.

126 Alcoff Linda and Gray Laura 'Survivor Discourse: Transgression or Recuperation?’ (1993) 18:2 Signs 260 at 275.

127 Nead Lynda 'Courtroom Sketching: Reflections on History, Law and the Image' in Freeman Michael (ed) Law and Popular Culture Vol 7 Oxford University Press Oxford 2004 p 173. 'The media often uses the presence of survivors for shock value and to pander to a sadistic voyeurism among viewers, focusing on the details of the violations with close-ups of survivors' anguished expressions.' Alcoff and Gray, as above at 262. On some of the ethical and professional challenges of interviewing and writing about survivors of trauma, see Moore Jina 'The Pornography Trap: How Not to Write about Rape' in Columbia Journalism Review Jan/Feb 2011 p. 14, available here: http://www.jinamoore.com/wpcontent/uploads/2011/02/moore.pdf; see The Dart Centre Guide for Reporting on Trauma and Violence, http://dartcenter.org/files/sexual\%20violence\%20tipsheet_final_13.07.11.pdf

128 Blocker above note 49 at 53.

129 See McNamee Eugene 'Writing the Rwandan Genocide: the Justice and Politics of Witnessing After the Event' (2007) 18:3 Law and Critique 309 at 311.

130 http://twitter.com/\#!/tejucole 
Representations play a greater role than their instrumental gains in any one context: they shape our capacity to conceive of problems, and enhancing or limiting our understandings. When the challenges that these women's testimonies offer to patriarchal notions of instinctual maternal love are rendered non-threatening by the assertion that the women still love their kids, the gendered object of humanitarian discourse is reinforced and the possibilities for re-thinking closed off. We can denounce genocidal rape as abhorrent while ignoring the extent to which its underlying and enabling patriarchal, neocolonial, and racialised dynamics continue to shape our vision of its survivors and their children. 